\title{
An Evaluation of Optimism and Life Satisfaction of Undergraduate Students in the School of Tourism and Hotel Management
}

\author{
Şafak Ünüvar ${ }^{1}$, Selahattin Avşaroğlu² \& Mustafa Uslu ${ }^{3}$ \\ ${ }^{1}$ School of Tourism and Hotel Management, Selçuk University, Konya, Turkey \\ ${ }^{2}$ Faculty of Education, Necmettin Erbakan University, Konya, Turkey \\ ${ }^{3}$ Faculty of Vocational Education, Selçuk University, Konya, Turkey \\ Correspondence: Şafak Ünüvar, School of Tourism and Hotel Management, Selçuk University, Alaeddin \\ Keykubat Campus, Selcuklu-Konya, Turkey. Tel: 90-332-223-4437. E-mail: safakunuvar@gmail.com
}

Received: July 27, 2012 Accepted: August 23, 2012 Online Published: September 20, 2012

doi:10.5539/ass.v8n12p140 URL: http://dx.doi.org/10.5539/ass.v8n12p140

\begin{abstract}
In recent years there are numerous institutions providing education in tourism sector which increase its importance,because of the need for qualified staff. School of Tourism and Hotel Managements are one of these institutions which provide the highest level of education. Due to the forefront of human element because of tourism sectors' structural caharcteristics the purpose of this study is to evaluate optimism and life satisfaction of the undergraduate tourism and hotel management students. "Optimism Scale" developed by Balc1 and Y1lmaz (2002) was used to measure students' optimism, and "Life Satisfaction" developed by Diener, Emmons, Larsen and Griffin (1985), translated into Turkish by Köker (1991) was used to measure students' life satisfaction. Element sampling method was used. The sample involved the students who enrolled at School of Tourism and Hotel Management, Selcuk University in Turkey, during the spring semester of 2010-2011 academic year $(n=479)$. Results showed that the students scored moderately on satisfaction and highly on optimism. Female students were more optimistic and satisfied than male students and the higher the level of income students had, the more optimistic and satisfied they were. Another result showed that there was a positive correlation between students' optimism and life satisfaction.
\end{abstract}

Keywords: optimism, self-esteem, life satisfaction, tourism education, subjective well-being

\section{Introduction}

Humans react differently when they come across with different situations in their daily lives. There lie individual differences and perception types underneath this difference (Freedman, Sears and Carlsmith, 1989). These ways of perception turn into behavioristic rituals (Kağıtçıbaşı, 1992). One of these is that an individual adopts an optimistic attitude against these events and situations (Kızılçelik, 1992). Therefore, they can develop some strategies for perception, interpretation, problem-solving and decision-making processes in their interpersonal relations (Cüceloğlu, 2003; Gençtan, 2007; Öner-Koruklu, 2010).

Optimism is a term, which involves feelings, expectations, planning, logic and actions (Balc1 and Y1lmaz, 2002; Gençoğlu, 2006). In this sense, optimism is both an emotion (Baumeister, Campbell, Krueger and Vohs, 2003) and a feature, which can also be developed by learning processes (Greenwald and Farnham, 2000). Goleman (2000) defines optimism as a strong emotion and an expectation towards the assumption that everything will be all right against all its difficulties and obstacles. Optimism is examined under two interrelated concepts; optimist tendency and optimist situation. Optimist tendency usually refers to the situation in which the individuals are expecting that good things will also happen besides the bad ones in the future, and the optimist situation refers to the situation in which individuals choose to be good even under special and limited circumstances (Daco, 1989).

Scheier and Carver (1992) emphasize that optimism is a process in which individuals hope for the best and expect positive results instead of negative ones in their daily lives. Goleman (2000) defines optimism as a strong emotion and an expectation towards the assumption that everything will be all right against all its difficulties and obstacles. Researchers point out that an optimist attitude contributes positively to the individuals against their hopeless, depressive and intensively stresses living conditions (McGinnis, 1998; Hart and Hittner, 1995; Seligman and Csikszentmihalyi, 2000). In another study, the effects of dispositional and situational optimism on 
mood and immune changes were investigated. Results showed that optimism was associated with better mood (Segerstrom, Taylor, Kemeny and Fahey 1998). Brissette, Schier, and Carver (2002) investigated the extent to which social support and coping account for the association between greater optimism and better adjustment to stressful life events. Results showed that greater optimism, assessed at the beginning of the 1st semester of school, was prospectively associated with smaller increases in stress and depression and greater increases in perceived social support (but not in friendship network size) over the course of the 1st semester of school. Therefore, optimism can be seen as a factor, which develops the life satisfaction of an individual.

Türküm (1999) explains optimism under the terms of comparative optimism and unrealistic optimism. Comparative optimism involves distortions of individuals related to the possibility of occurrence of positive and negative situations. When compared with others, the individual finds himself or herself at a possibility that coming across positive situations is much higher. The unrealistic optimism is defined as a perceptive tendency in which an individual believes that probable occurrence of positive situations is much more than it could be in real life, on the other hand, the probable occurrence of negative situations is much lower than it could be in real life. Weinstein (1989) defines unrealistic optimism terms as a belief in which an individual believes he or she comes across negative situations less than others and comes across positive situations more than others.

Optimism involves a power to resist all difficulties in order to maintain the life in an effective way in spite of all of its obstacles. This power has a strong connection with self-esteem (Steffenhagen, 1990; Scheier, Carver, Bridges, 1994; Gillham, Shatte, Reivich and Seligman, 2000). Leung, Moneta, and McBride (2005) found that optimism predicted life satisfaction directly and indirectly through self-esteem and relationship harmony. On the other hand, knowing that the things will not go all right may lead individuals to be under stress (Makin and Lindley, 1995). Pessimism, which represents the negative end of life vision and is an antonym to optimism, (Kümbül-Güler and Emeç, 2006) is defined as a negative attitude, which prevents individuals to make a step forward. Abdel-Khalek and Lester (2006) investigated the differences in, and correlates of, optimism and pessimism. They found that optimism was correlated with pessimism.

In this sense, Beck (2005) draws a parallel between pessimism and all ideas of depressive individuals. An easy-quitter pessimist individual develops a belief that the reasons of all bad events they come across are permanent. However, the optimists believe that those reasons are temporary (Gillham, Shatte, Reivich and Seligman, 2000). By following cognitive reconstruction techniques for such thoughts in a pessimist view as "Things are not going OK, life is meaningless, this situation will never change for me", successful processes may be obtained. In such cases where an individual cannot get over with or has difficulty in overcoming these situations, it also affects their life perception. Life perception can be claimed that it is an important term in an individual's life satisfaction.

Life satisfaction is an ability of an individual to develop a subjective point of view about his or her life quality under his or her own criterion. Hence, it has both an experiential and cognitive aspects (Rode, 2004; Tuzgöl-Dost, 2007). Life satisfaction is also defined as a process in which an individual tries to reach his or her own goals (Aysan and Bozkurt, 2004). According to Diener (1994), life satisfaction involves a satisfaction from the present life, a desire to change to their life, satisfaction from the past life, satisfaction from the future and the ideas of relatives about that person's life. Researchers (Herzberg, Mausner and Snyderman, 1959; Maslow, 1971; Freud, 1993; Judge and Larsen, 2001; Köroğlu, 2005) emphasize in general sense that satisfaction is an emotional and intrinsic recognition process in which a mental construction of an individual and its development are all involved. In this process, satisfaction is maintained by interaction of emotions and behaviors. Especially the thinking and feeling functions of an individual (Super, 1947; Yüksel 2003; Karahan and Sardoğan, 2004) play a crucial role to develop a cognitive point of view and to make a definition of satisfaction by reaching subjective experiences.

Satisfaction is the provision of expectations, requirements, wishes and desires. Life satisfaction is the situation obtained by the comparison of expectations of an individual (what he or she wants) and what he or she possesses (what he or she has got) (Özsoy-Karabulut, 2003). The perception of support is one of the aspects providing a life satisfaction for the individual (Strine, Chapman, Balluz, Moriarty and Mokdad, 2008). Life satisfaction can be defined as well being from such different points as happiness (Vara, 1999; Yee Ho, Cheung and Cheung, 2008) and the dominance of positive emotions over negative ones in daily relations (Aksaray et al, 1998).

Turkey welcomes millions of tourists every year thanks to the tourism supply. Especially in tourism where human element remains forefront and where machanization possibility is limited, touristic businesses' employees optimism level and life satisfaction level are expected to be high. There are many instituons and organizations in order to train qualified staff in tourism sector in Turkey. Universities which provide undergraduate education are the most highest level in these organizations and institutuions. 
University students can be referred as young people getting prepared for their future life. University life plays an important role in terms of both theoretical and field knowledge acquisition and also shaping their social roles. Getting adopted by their vocational and living spaces after school is very much related to their optimistic attitudes. Therefore, the purpose is to determine the optimism and life satisfaction levels of graduate students during their tourism training. In accordance with this purpose, these sub-goals are determined and data were collected.

1) What levels of life satisfaction and optimism the students have during their tourism training?

2) Are there any differences in terms of their gender and income levels according to the level of the life satisfaction and optimism of students during their tourism training?

3) Is there a significant connection between the life satisfaction and optimism levels of students?

\section{Method}

In this part, the type of research, sample, data collection procedures and statistical methods to evaluate the data collected are presented.

\subsection{Research Model}

This research has a general scanning model (Büyüköztürk et al, 2010). A comparative correlational scanning is made between dependent and independent variables of the research. The data are collected to determine the optimism and life expectation levels of students during their tourism training in this research. Another aim of this research is to see how we can predict optimism by life satisfaction.

\subsection{Sample}

There are many schols providing undergraduate education in Turkey. The research is held by the participation of students during their training in Konya which is the most biggest city in Turkey at Tourism and Hotel Management at Selcuk University in Turkey, which is one of the biggest university in Turkey, both in the main campus and in other provinces. The research samples are selected by random sampling method among the students in the research group. The research sample involves 186 female and 293 male, 479 in total.

\subsection{Data Collection Procedures}

\subsubsection{Optimism Scale}

In the research, an "Optimism Scale" developed by Balc1 and Y1lmaz (2002) is used in order to determine the optimism levels of the students. The scale is developed in order to measure the optimism levels of university students. Developed as a 4-scale Likert type, the Optimism Scale involves 24 items. The scale has an Cronbach Alpha number of .96 and reliability coefficient of .91 . The lowest point an individual can get by using this scale is 24 and the highest 96. The higher the score is, the more optimist the individuals are (Balc1 and Y1lmaz, 2002).

\subsubsection{Life Satisfaction Scale}

"The Life Satisfaction Scale" developed by Diener, Emmons, Larsen and Griffin (1985), translated into Turkish by Köker (1991) is used in order to determine the life satisfaction levels. In the results of reliability studies of this scale, it is calculated that the reliability of test-retest is $\mathrm{r}=.85$, item-test correlations are between .71 and .80 .

\subsubsection{Data Analysis}

In the research, the data collected from the scales were measured by SPSS 19.00. Pearson Product-Moment Correlation technique was used to present the relation between the optimism and life satisfaction levels of the students in Tourism and Hotel Management. Regression analysis was used to test if the optimism was significant to explain the life satisfaction.

\section{Findings}

Female had significantly higher levels of life satisfaction and being more optimistic than men when the points from optimism and life satisfaction scales are taken into consideration in terms of gender in Table 2. An increase in the income level indicates an increase in optimism when the points from optimism and life satisfaction scales are taken into consideration in terms of income levels of students. Also, there is an increase in life satisfaction, as the income levels get higher. According to the $\mathrm{F}$ test, the differences between the income levels give a significant difference between optimism and life satisfaction levels. According to the Tukey test, there is a significant difference between the ones with low income and the ones with high income when the optimism levels of students are compared in terms of their income levels. 
Table 1. Table of optimism and life satisfaction $n, \overline{\mathbf{x}}, \mathrm{SD}$

\begin{tabular}{lccc}
\hline & $\mathrm{n}$ & $\overline{\mathbf{x}}$ & $\mathrm{SD}$ \\
\hline Life Satisfaction & 479 & 23.45 & 6.19 \\
Optimism & 479 & 75.53 & 11.40 \\
\hline
\end{tabular}

When Table 1 is examined, the life satisfaction indicates a medium level $(\overline{\mathbf{X}}: 23.45)$ when the points of the scale (min: 7, max: 49 points; 7-scale Likert type) are taken into consideration. And the optimism levels indicate a higher level (min: 24; max: 96 points; 4-scale Likert type) ( $\overline{\mathbf{X}}: 75.53)$.

According to the Tukey test, when the life satisfaction levels of students are compared in terms of their income levels, there is also a significant difference between the ones who say "Not Sufficient" and the ones with "Sufficient" or "Quite Sufficient", and between the ones who say "Insufficient" and the ones with "Sufficient" or "Quite Sufficient" $(\mathrm{P}<0.05)$

Table 2. Table for optimism levels and life satisfaction levels; gender and income levels, n, X, SD, p, F

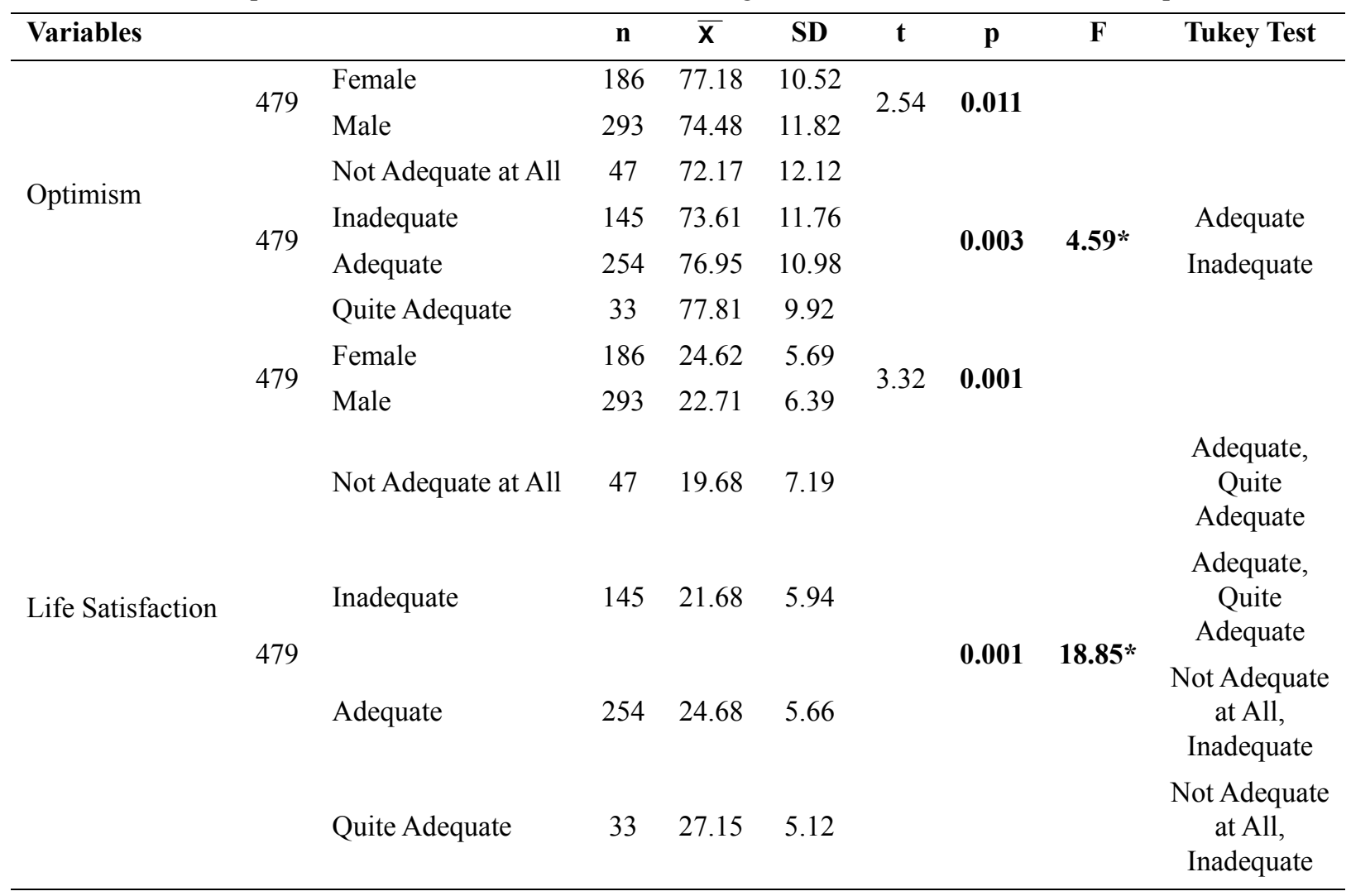

A positive relation was found between the variables of optimism and life satisfaction when Table 3 is examined. This situation means that the optimism and life satisfaction have the same variable coefficient.

Table 3. The relation between life satisfaction and optimism levels of students

\begin{tabular}{lc}
\hline & Life Satisfaction \\
\hline Optimism & $.359(\mathrm{p}<.001)$ \\
\hline $\mathrm{P}<.05$ &
\end{tabular}

It is seen that the optimism variable has a significantly medium relation over life satisfaction. Therefore, it is possible to say that the levels of life satisfaction increases as the optimism levels of students go higher.

\section{Results and Discussion}

Turkey, with its natural and cultural values in recent years has become an important tourist destination. Tourism, which has become a mass movement, especially numerous businesses providing services are available. Today, the need for qualified staff to serve tourists from tourism businesses felt more than ever before. Employees in the tourism sector should be at the highest level in terms of both personality development and professional development. In this research, the purpose is to determine the optimism and life satisfaction levels of students 
during their training at Tourism and Hotel Management. In the view of this research, data are collected by the procedures as defined earlier. According to the findings of the research, the students with training at Tourism Management had a medium level of life satisfaction. Life satisfaction may be regarded as a well being process on subjective perceptions in their living spaces. Although there are individual differences among students (Freedman, Sears and Carlsmith, 1989), there is a medium level of life perception in general as the average points are taken into consideration. This case is presented in Table 1 (min: 7; max: 49 points; 7 -scale Likert type) $(\overline{\mathbf{X}}:$ 23.45). Another finding in the research is that the students have a high level of optimism perception. This case is presented in Table 1. (min: 24; max: 96 points; 4-scale Likert type) ( $\overline{\mathbf{X}}: 75.53)$. In the research, optimism is indicated as a contribution to have a positive view for the individuals in terms of living conditions (Scheier and Carver, 1992; McGinnis, 1998; Hart and Hittner, 1995; Seligman and Csikszentmihalyi, 2000). In this sense, the student develops a subjective point of view about the quality of life in terms of his or her own parameters. In this process, both the experiential and the cognitive factors (Rode, 2004; Tuzgöl-Dost, 2007) may be regarded as important elements to determine the levels of life satisfaction.

In the research, results show that female students have a higher level of optimism and life satisfaction than male students. In parallel to the findings of this research, Tuzgöl-Dost (2007) determines that the levels of life satisfaction for female students are higher than the male ones. In a similar study, Aymir (2004) determines that it is significantly higher for female than male both in acquisition and frame of mind in terms of their optimism. In some other studies, it is emphasized that male students have a higher level of optimism. For example, El-Anzi (2005) determines that the optimism levels for male students are higher than female students. In another study conducted by Açıköz (2006), he determines that the optimism levels for male students are higher than female students. Puskar et al (1999) also finds the average levels of optimism for female students are much lower than the male ones, but this difference made no statistical significance.

An optimistic point of view may be argued to have a relation to the environmental acquisition. In other words, an individual may be affected by environmental factors such as mother and father attitudes, giving him or her an optimistic or a pessimistic attitude. In this frame, the inner world of an individual and the interaction with the environment may be shaped by a social skill education (Deniz, 2011). Thus, Şimşek (2003) emphasizes in one of his research that the individuals in the experimental group have a significant increase in their un-functional thoughts and the levels of optimism when compared to control group. Therefore, the parents, school and environmental characteristics may be regarded as basic elements affecting the point of view of an individual during his or her development process against the events and situations. When the points of students taken from the scales of optimism and life satisfaction in terms of their income levels are regarded, the more the income level is, the more increase is found in their optimism. Similarly, it is seen that the level of life satisfaction gets higher as the income level increases. According to this result, the perception of income level is an element, which affects the life satisfaction.

Another important finding of this research is that there is a positive relation between the variables of optimism and life satisfaction. This case means optimism and life satisfaction have the same variable. In another research, Chang, Olivares and Zurilla (1997) claims optimism and pessimism to be significant correlates of life satisfaction. In another similar study, Bailey, Eng, Frisch, and Snyder, (2007) emphasizes hope and optimism as related to life satisfaction. According to Lucas and Diener (1996), life satisfaction is discriminable from optimism. Optimism is separable from trait measures of negative effect. It is seen that the optimism variable has a significantly medium relation over the life satisfaction. Therefore, it is possible to argue that life satisfaction levels get higher as the optimism levels increase. Cummins and Nistico (2002) found that the need for optimism regarding oneself was intimately linked to life satisfaction. Overall, these findings highlight a considerable degree of co-variation between self-esteem, optimism, and the maintenance of life satisfaction. Besides, it is possible to claim that optimism may affect the academic success. Thus, Nonis and Wright (2003), in their research, claims that individuals who are high in situational optimism would demonstrate a stronger relationship than individuals who were low in situational optimism. Analyses revealed students who were high in achievement striving and high in situational optimism were better performers. Determining that there is a positive relation between optimism and life satisfaction in the research, it indicates that optimism is very important. It is important in terms of affecting the life satisfaction and being related to the living perceptions by getting an optimistic point of view. This process begins with parents' attitudes in the family environment and goes on at school and environmental conditions. Hence, a psychological assistance may be helpful both for students and their parents in order to have an optimistic view. In this way, individuals with a higher self-esteem, self-contend and self-reconciliation may be brought into the society.

To determine life satisfaction and optimism of Students who study in Tourism and Hotel Management 
departments to work in Tourism sector will shed light to other academic studies. Education and group counselling may be provided to make their life perceptions more optimistic. Because a positive correlation was found between life satisfaction and optimistic perspective. One of the most important goal of human being is to keep life stisfaction at high level. Therefore, it is important to to determine the relationship between tourism employee's life satisfaction and optimism.

The findings of this research are only limited by the data gathered from the students in Tourism and Hotel Management at Selcuk University in Turkey. The findings obtained by the analysis may be generalized in this view. The factors affecting the optimism and life satisfaction of the students may be multi-variable. Therefore, other studies may be conducted on determining the relationships among other variables. We would live to present our deep gratitude to the students who sincerely answered these scales and all conductors who supported this research at each stage during the data collection process.

\section{References}

Abdel-Khalek, A., \& Lester, D. (2006). Optimism and Pessimism in Kuwaiti and American College Students. International Journal of Social Psychology, 52(2), 110-126. http://dx.doi.org/10.1177/0020764006062092

Açıkgöz, S. (2006). Üniversite Öğrencilerinin Beslenme Alışkanlıkları ile Özyetkinlik ve İyimserlik İlişkisi: Ankara Üniversitesi Örneği. (Yayımlanmamış Yüksek Lisans Tezi). Ankara: Ankara Üniversitesi.

Aksaray, S., Yıldız, A., \& Ergün, A. (1998, Eylül). Huzurevi ve Evde Yaşayan Yaşlıların Umutsuzluk Düzeyleri. 1. Ulusal Evde Bakım Kongresi. İstanbul, Turkey, 24-26.

Aymir, C. (2004). Sigorta Çalışanlarının Performansını Yordayan Bir Faktör Olarak İyimser Kötümser Açıklama Tarzı. (Yayımlanmamış Yüksek Lisans Tezi), İstanbul: Marmara Üniversitesi.

Aysan, F., \& Bozkurt, N. (2004, Temmuz). Okul Psikolojik Danışmanlarının Yaşam Doyumu Stresle Başa Çıkma Stratejileri ile Olumsuz Otomatik Düşünceleri: İzmir İli Örneklemi. Ulusal Eğitim Bilimleri Kurultayl. İnönü Üniversitesi, Malatya, Turkey, 6-9.

Bailey, T. C., Eng, W., Frisch, M. B., \& Snyder, C. R. (2007). Hope and Optimism as Related to Life Satisfaction. The Journal of Positive Psychology, 2(3), 168-175. http://dx.doi.org/10.1080/17439760701409546

Balcı, S., \& Yılmaz, M. (2002). İyimserlik Ölçeğinin Geçerlilik ve Güvenilirlik Çalışması. On dokuz Mayıs Üniversitesi Eğitim Bilimleri Fakültesi Dergisi, 14, 54-60.

Baumeister, R. F., Campbell, J. D., Krueger, J. I., \& Vohs, K. D. (2003). Does High Self-Esteem Cause Better Performance, Interpersonal Success, Happiness, or Healthier Lifestyles? Psychological Science in the Public Interest, 4(1), 1-43. http://dx.doi.org/10.1111/1529-1006.01431

Beck, A. (2005). Bilişsel Terapi ve Duygusal Bozukluklar (Çev. A. Türkcan). İstanbul, Liter Yayıncıllk.

Brissette, I., Scheier, M. F., \& Carver, C. S. (2002). The Role of Optimism in Social Network Development, Coping, and Psychological Adjustment During a Life Transition. Journal of Personality and Social Psychology, 82(1), 102-111. http://dx.doi.org/10.1037/0022-3514.82.1.102

Büyüköztürk, Ş., Çakmak-Kılıç, E., Akgün, Ö. E., Karadeniz, Ş., \& Demirel, F. (2010). Bilimsel Araştırma Yöntemleri. Ankara, Pegem Akademi Yayınları.

Chang, E. C., Olivares, A. M., \& Zurilla, T. J. D. (1997). Optimism and Pessimism as Partially Independent Constructs: Relationships to Positive and Negative Effectivity and Psychological Well-beeing. Personality and Individual Differences, 23(3), 433-440.

Cüceloğlu, D. (2003). İnsan ve Davranışı. İstanbul, Remzi Kitabevi.

Cummins, R. A., \& Nistico, H. (2002). Maintaining Life Satisfaction: The Role of Positive Cognitive Bias. Journal of Happiness Studies, 3, 37-69. http://dx.doi.org/10.1023/A:1015678915305

Daco, P. (1989). Çağdaş Psikolojinin Olağanüstü Başarıları. İstanbul, İnkılap Kitabevi.

Deniz, M. E. (2011). Psikolojik Danışma ve Rehberlik: Kişisel Rehberlik. (Edit: M.E. Deniz \& A. Erözkan). Ankara, Maya Akademi.

Diener, E. (1994). Assessing Subjective Well-Being: Progress and Opportunities. Social Indicators Research, 31, 103-157. http://dx.doi.org/10.1007/BF01207052

Diener, E., Emmons, R. A., Larsen, R. J., \& Griffin, S. (1985). The Satisfaction with Life Scale. Journal of Personality Assessment, 49(1), 71-75. http://dx.doi.org/10.1207/s15327752jpa4901_13 
El-Anzi, F. O. (2005). Akademic Achievement and Its Relationship with Anxiety, Self-Esteem, Optimism, and Pessimism, in Kuwaiti Students. Social Behavior and Personality, 33(1), 95-104. http://dx.doi.org/10.2224/sbp.2005.33.1.95

Freedman, J. L., Sears, D. O., \& Carlsmith, J. M. (1989). Sosyal Psikoloji. (Çev: A. Dönmez). İstanbul, Ara Yayıncilik.

Freud, S. (1993). Psikanalize Giriş: Genel Nevroz Öğretisi. (Çev: Koptagel-İlal, G). İstanbul, Star Yaprak Yayıncilik.

Gençoğlu, C. (2006). Üniversite Öğrencilerinin İyimserlik Düzeyleri ile Kişilik Özellikleri Arasındaki İlişkinin İncelenmesi. Yayımlanmamış Yüksek Lisans Tezi. Samsun: Ondokuz Mayıs Üniversitesi

Gençtan, E. (2007). Insan Olmak. İstanbul: Metis Yayıncılık.

Gillham, J. E., Shatta, A. J., Reivich, K. J., \& Seligman, M. E. (2000) Optimism, Pessimism and Explanatory Style: Optimism and Pessimism. (Edit: E.C. Chang). Washington DC: American Psychological Association.

Goleman, D. (2000). Duygusal Zeka. İstanbul, Varlık Yayınları.

Greenwald, A. G., \& Farnham, S. D. (2000). Using the Implicit Association Test to Measure Self-Esteem and Self-Concept. Journal of Personality and Social Psychology, 79, 1022-1038. http://dx.doi.org/10.1037/0022-3514.79.6.1022

Hart, E., \& Hittner, B. (1995). Optimism and Pessimism Associations to Coping and Anger Reactivity. Personality and Individual Differences, 6, 827-839. http://dx.doi.org/10.1016/S0191-8869(95)00104-2

Herzberg, F. B., Mausner, B., \& Synderman, B. (1959). The Motivation of Work. New York: Viley.

Judge, T. A., \& Larsen, R. J. (2001). Dispositional Affect and Job Satisfaction: A Review and Theoretical Extension. Journal of Organizational Behavior and Human Decision Processes, 86, 67-98. http://dx.doi.org/10.1006/obhd.2001.2973

Kağıtçıbaşı, Ç. (1992). İnsan ve İnsanlar. Basım. İstanbul, Evrim Yayıncılık.

Karahan, T. F., \& Sardoğan, M. E. (2004). Psikolojik Danışma ve Psikoterapide Kuramlar. Samsun, Deniz Kültür Yayınları.

Kızılçelik, S. (1992). Sosyoloji Teorileri 1. Konya, Mimoza Yayınları.

Köker, S. (1991). Normal ve Sorunlu Ergenlerin Yaşam Doyumu Düzeylerinin Karşılaştııılması. (Yayınlanmamış Yüksek Lisans Tezi). Ankara: Ankara Üniversitesi.

Köroğlu, E. (2005). Bilişsel-Davranış̧̧ı Psikoterapiler. Ankara, Hyl Yayıncılık.

Kümbül-Güler, B., \& Emeç, H. (2006). Yaşam Memnuniyeti ve Akademik Başarıda İyimserlik Etkisi. Dokuz Eylül Üniversitesi, İktisadi ve İdari Bilimler Fakültesi Dergisi, 21(2), 129-149.

Leung, W. C., Moneta, G. B., \& McBride, C. C. (2005). Think Positively and Feel Positively: Optimism and Life Satisfaction in Late Life. Aging and Human Development, 61(4), 335-365. http://dx.doi.org/10.2190/FQTB-EBAJ-H9WP-LMYA

Lucas, R. E., \& Diener, E. (1996). Discriminant Validity of well-being Measures. Journal of personality and social psychology, 71(3), 616-628. http://dx.doi.org/10.1037/0022-3514.71.3.616

Makin, E. P., \& Lindley, P. A. (1995) Pozitif Stres Yönetimi, (Çev. A. Arslan). İstanbul: Rota Yayınları.

Maslow, A. (1971). The Farther Reaches of Human Nature. New York, Viking.

McGinnis, A. L. (1998) İyimserliğin Gücü, (Çev: A. Kayaş). İstanbul, Beyaz Yayınları.

Nonis, S. A., \& Wright, D. (2003). Moderating Effects of Achievement Striving and Situational Optimism on the Relationship Between Ability and Performance Outcomes of College Students. Research in Higher Education, 44(3), 327-345. http://dx.doi.org/10.1023/A:1023029815944

Öner-Koruklu, N. (2010). Kişilerarası İletişim ve Etkili İletişim. (Edit: A. Kaya). Ankara, Pegem Akademi.

Özsoy-Karabulut, Ö. (2003). Yaşlılarda Yaşam Doyumu. Turkish Journal of Geriatrics, 6(2), 72-74.

Puskar, K. R., Sereika, S. M., Lamb, J., Tusaie- Mumford, K., \& McGuinness, T. (1999). Optimism and Its Relationship to Depression. Coping, Anger, and Life Events in Rural Adolescents. Issues in Mental Health Nursing, 20, 115-130. http://dx.doi.org/10.1080/016128499248709

Rode, J. C. (2004). Job Satisfaction and Life Satisfaction Revisited: A Longitudinal Test of an Integrated Model. 
Human Relations, 57(9), 1205-1231. http://dx.doi.org/10.1177/0018726704047143

Scheier, M. F., \& Carver, S. (1992). Effect of Optimism on Psychological and Physical Well-Being: Theoretical Over-View and Empirical Update. Cognitive Therapy and Research, 16(2) 201-228. http://dx.doi.org/10.1007/BF01173489

Scheier, M. F., Carver, C. S, \& Bridges, M. W. (1994). Distinguishing Optimism from Neuroticism (and Trait Anxiety, Self-Mastery and Self-Esteem): A Reevaluation of the Life Orientation Test. Journal of Personality and Social Psychology, 67(6), 1063-1078. http://dx.doi.org/10.1037/0022-3514.67.6.1063

Segerstrom, S. C., Taylor, S. E., Kemeny, M. E., \& Fahey, J. L. (1998). Optimism is Associated with Mood, Coping, and İmmune Change in Response to Stress. Journal of personality and Social Psychology, 74(6), 1646-1655. http://dx.doi.org/10.1037/0022-3514.74.6.1646

Seligman, M. E., \& Csikszentmihalyi, M. (2000). Positive Psychology: An Introduction. American Psychologist, 55(1), 5-14. http://dx.doi.org/10.1037/0003-066X.55.1.5

Şimşek, E. (2003). Bilişsel Davranışçı Yaklaşımla Bütünleştirilmiş Film Terapisi ve Rol Değiştirme Uygulamasının Üniversite Öğrencilerinin İşlevsel Olmayan Düşüncelerinin Azalmasında ve İyimserliklerine Etkisi. (Yayımlanmamış Doktora Tezi). Ankara: Ankara Üniversitesi.

Steffenhagen, R. A. (1990). Self-Esteem Therapy. New York: An imprint of Greenwood Publishing Group, Inc.

Strine, T. W., Chapman, D. P., Balluz, L. S., Moriarty, D. G., \& Mokdad, A. H. (2008). The Associations Between Life Satisfaction and Healthrelated Quality of Life, Chronic Illness, and Health Behaviors among U.S. Community-dwelling Adults. Journal Community Health, 33, 40-50. http://dx.doi.org/10.1007/s10900-007-9066-4

Super, D. E. (1947). Vocational Interest and Vocational Choice. Educational and Psychological Measurement, 7 , 375-384.

Türküm, S. (1999). L̇yimserlik ve Stresle Başa Çıkma. Eskişehir: Anadolu Üniversitesi Yayınları.

Tuzgöl-Dost, M. (2007). Üniversite Öğrencilerinin Yaşam Doyumunun Bazı Değişkenlere Göre İncelenmesi. Pamukkale Üniversitesi Eğitim Fakültesi Dergisi, 2(22), 132-143.

Vara, Ş. (1999). Yoğun Bakım Hemşirelerinde İş doyumu ve Genel Yaşam Doyumu Arasındaki İlişkilerin İncelenmesi. (Yayınlanmamış Yüksek Lisan Tezi). İzmir: Ege Üniversitesi

Yee Ho, M., Cheung, F. M., \& Cheung, S. F. (2008). Personality and Life Events as Predictors of Adolescents' Life Satisfaction: Do Life Events Mediate the Link Between Personality and Life Satisfaction. Soc Indic Res, 89, 457-471. http://dx.doi.org/10.1007/s11205-008-9243-6

Yüksel, İ. (2003). Hemşirelerin İş Güçlüğü Faktörlerinin Belirlenmesi İş Doyumu ve Örgütsel Bağll11k Üzerindeki Etkisinin Analizi. Marmara Üniversitesi Sosyal Bilimler Enstitüsü Dergisi, 5(20), 131-139. 